\title{
СІМЕЙНИЙ КОНФЛІКТ: ПРИЧИНИ ВИНИКНЕННЯ, ПОПЕРЕДЖЕННЯ, ВРЕГУЛЮВАННЯ
}

\author{
т. о. Кругла \\ ДВНЗ «Тернопільський державний медичний університет \\ імені І. Я. Горбачевського МОЗ Украӥни»
}

У статті висвітлено причини виникнення сімейних конфліктів. Узагальнено інформацію щодо попередження та врегулювання конфліктів у сім’ї. Проаналізовано стан теоретичної розробки досліджуваної проблеми.

\section{FAMILY CONFLICT: CAUSES, PREVENTION, RESOLUTION}

\section{T. O. Krugla}

\section{Horbachevsky Ternopil State Medical University}

The article is devoted to identifying the causes of conflict in the family. Summarized information is relative to the prevention and resolution of conflicts in the family. It analyzes the theoretical development of the problem under study.

Вступ. Проблема конфліктів $є$ надзвичайно актуальною для сучасного суспільства. Ними буквально пронизані всі сфери життєдіяльності людини. Конфлікти різного роду та походження відзначаються у межах окремих держав, на рівні регіонів, в межах окремих населених пунктів, а також на міжнаціональному рівні. Вони мають досить широку варіативність свого підґрунтя, що приймає політичне, міжнаціональне, економічне або будь-яке інше забарвлення.

Сімейні конфлікти стали широко розповсюдженим явищем, що свідчить про дисгармонію в сімейних стосунках. Проблема виявлення сутності, причин, форм прояву конфліктів $\epsilon$ на сьогодні особливо актуальною для науки, тому що в період трансформації суспільства зріс показник розлучень, особливо серед молодих сімей.

Відтак, порушуючи або навіть руйнуючи простір звичної соціальної організації людства, конфлікти на цьому не зупиняються й проникають у сферу приватного життя кожної окремої людини - у ії сім'ю, подружні стосунки.

На вчинки, що призводять до конфлікту в сімейних стосунках, слід завжди звертати увагу, бо сім'я - це надзвичайно важливий соціальний інститут у державі,

(ㄱ Т. О. Кругла, 2017 який $є$ гарантом майбутнього. Недаремно кажуть: міцна сім'я - міцна держава. Тому в системі політики держави сім'я повинна займати гідне місце [1].

Саме питання поширення і вирішення цієї проблеми в сучасному суспільстві, на мою думку, є недостатньо вивчене, що й зумовило вибір теми дослідження.

Основна частина. Сімейний конфлікт явище досить поширене. І це не дивно, адже саме в родині відбуваються тісні контакти між людьми. При цьому кожний з членів сім'і хоче жити згідно зі своїми ідеями і поглядами, і не завжди виходить порівняти їх зі звичками і переконаннями інших членів сім'і. На цьому ґрунті і відбуваються сімейні конфлікти. Але іноді виникає конфронтація, коли люди не можуть зрозуміти один одного і приходять до неправильного висновку. Це породжує претензії і образи, і не завжди виходить врегулювати проблему мирним шляхом.

Лев Толстой мудро зауважив, що «... кожна нещаслива сім'я нещаслива по-своєму». Виходить, що сімейні конфлікти та їх причини можуть бути зовсім різними, але найчастіше вони пов'язані між собою. Ми готові провести хоч і не повний, але досконалий перелік недоліків у сімейних стосунках, які можуть істотно вплинути на якість взаємовідносин, так і на подальше психологічне благополуччя сім'ї. 
У ході вивчення проблеми сімейного конфлікту виявлено основні причини його початку, до яких належать:

- наміри змінити партнера. Як це не дивно, але ті, від кого ми вимагаємо змін, зовсім не хочуть бути глиною, з якої можна зліпити все, що завгодно. У них $\epsilon$ свої переконання, уявлення про правила сімейного життя, цінності, на які вони спираються;

- егоїзм;

- ревнощі;

- невміння спілкуватися один з одним. Непорозуміння як результат небажання вести діалог;

- обмеження свободи дій, самовираження членів сім'i;

- незадоволення потреби в позитивних емоціях (відсутність ласки, турботи, уваги й розуміння);

- побутова невлаштованість;

- зрада;

- неповага один до одного;

- різні погляди на сімейне життя;

- невідповідність темпераментів;

- шкідливі звички одного з подружжя та пов'язані з ними наслідки;

- небажання допомагати один одному;

- матеріальні проблеми, які складно вирішити;

- розбіжності в духовних інтересах.

Привертає увагу підхід дослідників В. К. Мягера та Т. М. Мішиної, які вважають, що конфлікт у сім'і виникає у тому випадку, коли обидва учасники прагнуть оволодіти одним і тим самим об'єктом, зайняти одне і те ж місце чи виняткове положення, грати несумісні ролі, досягнути різноспрямованих цілей [2]. Окрім того, у суспільній свідомості конфлікт, як правило, асоціюється з тим, чого не має бути у сім'ї. Головним $\epsilon$ висновок про те, що конфлікт містить можливість виходу на новий рівень взаємин, знаходження нових можливостей. Успішні сім'ї відрізняються від проблемних не відсутністю чи низькою частотою конфліктів, а незначною їх глибиною і безболісністю $[2,3]$.

Відомий дослідник А. І. Кочетов [4] називає сім основних причин сімейних конфліктів:

- порушення етики подружніх стосунків (зрада, ревнощі). Звичайно зрада одного із подружжя $є$ травмуючою для будь-якої людини, так, вона переживається як зрадництво, обман і відсутність любові. Безпричинні ревнощі сприймаються як недовіра з боку партнера й викликають відчуття образи;

- біологічна несумісність. Досить часто шлюби укладаються по любові, що є вищим почуттям, яке зв'язане значною мірою із загальним світоглядом, ціннісними орієнтаціями, системою мотивації й спрямованістю особистості. Однак особливості нервової системи, не завжди прийняті майбутнім подружжям до уваги, можуть стати причиною сексуальної незадоволеності або розбіжності біоритмів «жайворонка» і «сови»;

- непорозуміння подружжя (одного з них) з людьми, які їх оточують, - родичами, знайомими, товаришами і т. д. Звичайно, найпоширенішою причиною конфліктів $\epsilon$ некоректне ставлення одного з подружжя до батьків іншого партнера. Багато батьків, які опікуються сімейним щастям своєї вже дорослої дитини, порушують структуру стосунків молодих пар, створюючи конфліктні ситуації;

- несумісність інтересів і потреб. Досить часто подібність інтересів і потреб лежить в основі створення сім'ї, однак вони не можуть повністю збігатися у двох різних людей, а також змінюються із часом, що спричиняє непорозуміння;

- відмінність педагогічних позицій стосовно дитини. Виховуючи дитину, батьки використовують непослідовний стиль так само, як і різні цілі й засоби виховання. Що не тільки не приносить бажаного ефекту, але й просто робить дитину нещасною;

- наявність особистісних недоліків або негативних якостей в одного, а часом і в обох. Брутальність, запальність, брехливість, неохайність і багато інших якостей викликають незадоволення в другої половини, і тільки наявність у неї такої позитивної якості, як терпіння, здатне запобігти подружній сварці;

- відсутність взаєморозуміння між батьками й дітьми. Якщо попередні причини в основному стосувалися подружніх стосунків, то остання належить до проблем батьків і дітей. По суті вона ґрунтується на різних цінностях, потребах й інтересах різних поколінь і невміння розуміти іншу точку зору.

Відповідно із дослідницькими фактами фахівців, гострота конфліктів, їх частота, сила емоційних вибухів, контроль за власною поведінкою, тактика і стратегія поведінки партнерів у різних конфліктних ситуаціях залежить також від індивідуальних особливостей, темпераменту і характеру.

Н. В. Гришина вказує на взаємозв'язок конфліктності з деякими особливостями особистості: нестриманістю, імпульсивністю [5].

У дослідженнях А. П. Мусакіної було виявлено, що жінкам дружелюбним, комунікабельним краще вдається створити сім'ю і зберегти ії. Водночас такі жінки самі частіше бувають задоволені шлюбом. Окрім того, 
чим більше жінка прагне досягти задоволення від своїх інтересів, тим більше труднощів виникає при ії спілкуванні з чоловіком і дітьми. Разом з тим, чим вищий рівень домінантності жінки, тим менше згоди між партнерами у конфліктних ситуаціях, які зумовлені порушенням рольових очікувань [6].

Виникнення сімейного конфлікту, на думку авторів, залежить не лише від об'єктивних причин (наприклад, від специфіки умов перебігу конфлікту і характеристик його учасників), але й від суб'єктивних факторів уявлень учасників конфлікту про самих себе (про власні потреби, мотиви, цінності) і про свого шлюбного партнера [7].

Довірливе спілкування партнерів $\epsilon$ запорукою успішних подружніх взаємин. 3 огляду на це, будьякий конфлікт означає, що партнери просто не можуть нормально домовитися з якогось приводу. Водночас, Ю. Е. Альошина стверджує, що скарги на труднощі у спілкуванні досить рідко звучать у партнерів, які конфліктують. Лише в процесі консультування у подружньої пари виникають і формулюються скарги, що безпосередньо пов'язані зі спілкуванням [8].

Попередження сімейних конфліктів залежить від усіх членів сім'ї і насамперед від самих чоловіка і дружини. При цьому слід мати на увазі, що деякі дрібні сімейні сварки можуть мати позитивну спрямованість, допомагаючи прийти до згоди зі спірних питань і запобігти більш глибокому конфлікту. Але, у більшості випадків, сімейні конфлікти допускати не варто.

Там, де подружжя прагне до вдосконалення стосунків, конфлікти неминучі. Розв'язання конфлікту сприяє розвитку сім'ї, новому рівню спілкування, стиранню відмінностей [9].

Поза сумнівом, першою дією, що створює передумову вирішення конфлікту, є уміння визначити, в чому полягають істинні причини конфлікту. Істинну причину конфлікту досить часто приховує одна або обидві конфліктуючі сторони. Завдання встановити істинну причину конфлікту не просте. Воно вимагає доброго знання психології людини. Якщо причина конфлікту визначена правильно, то стає зрозумілою і конфліктна ситуація, а отже, у такому разі легше визначити найприйнятніші способи вирішення конфлікту.

Поступатися повинні обидва. Але першим повинен той, хто мудріший, краще розуміє, що небажання і невміння поступатися - шлях, що призводить до сварок і нерідко - до розлучень.
Дуже важливо навчитися такту і витримці, вмінню переконливо і аргументовано викладати власну точку зору. якщо ж переконати чоловіка не вдається, краще припинити суперечку. Найголовніше - не перетворити сімейні суперечки на сварки, дискусії - на скандали, а треба навчитися взаємодіяти з батьками і родичами, а найважливіше - навчитися поважати один одного [10].

Висновки. Узагальнюючи вищевикладене, можна зробити висновок, що виникнення сімейних конфліктів пов'язане із прагненням людей задовольняти ті або інші потреби або створити умови для їхнього задоволення без врахування інтересів іншої сторони конфлікту або члена сім'і.

Справжні причини конфлікту складно виявити через різні психологічні моменти. По-перше, у будьякому конфлікті раціональний початок, як правило, прихований за емоціями. По-друге, справжні причини конфлікту можуть бути надійно приховані та психологічно захищені в підсвідомості й проявлятися на поверхні тільки у вигляді прийнятних для Я-концепції мотивів. По-третє, причини конфліктів можуть бути невловимими через так званий закон кругової каузальності (причинності) сімейних стосунків, який проявляється й у подружніх конфліктах.

Отже, для успішного розв'язання конфлікту необхідно:

- бажання обох сторін його вирішити. Але якщо таке бажання буде виявлено хоча 6 однією із сторін, то й це дасть більше можливостей іншій стороні для зустрічного кроку;

- зробити перший крок на шляху до розв'язання конфлікту. Це завжди досить складно: кожний вважає, що поступитися повинен інший. Тому готовність до розв'язання конфлікту, виявлена однієї із сторін, може зіграти вирішальну роль у розв'язанні конфлікту в цілому.

Основними шляхами попередження конфліктів $\epsilon$ побудова сімейних стосунків на засадах рівноправності, взаємної відповідальності, довіри і пошани.

Аналіз науково-психологічної літератури з досліджуваної проблеми засвідчив, що проблеми причин виникнення, незважаючи на їх актуальність і важливе практичне значення, поки що вивчені недостатньо.

Тому, перспективами подальшого дослідження $\epsilon$ пошук ефективних методів вирішення сімейних конфліктів, спрямованих на поліпшення сімейного клімату, стосунків. 


\section{СПИСОК ЛІТЕРАТУРИ}

1. Пірен М. І. Конфліктологія : підручник / М. І. Пірен. К. : МАУП, 2003. - 360 с.

2. Мягер В. К. Сімейна психотерапія: керівництво з психотерапії / В. К. Мягер, Т. М. Мішина. - Л. : Медицина, 2000.

3. Андреева Т. В. Психология современной семьи : монография / Т. В. Андреева. - СПб. : Речь, 2005. - 436 с.

4. Кочетов А. И. Начало семейной жизни / А. И. Кочетов, А. А. Логинов // Мужчина и женщина: отношения полов. Мн. : Полымя, 1989. - 447 с.

5. Гришина Н. В. Психология конфликта / Н. В. Гришина.СПб. : Питер, 2009. - 544 с.

6. Андреева Т. В. Социально-психологические особенности замужних и разведенных женщин / Т. В. Андреева, А. П. Мусакина / Ананьевские чтения - 99 : Тез. научн.-практ. конф., 26-28 окт. 1999 г. - СПб. : изд. СанктПетербургского университета, 1999.

7. Левкович В. Методика диагностики супружеских отношений / В. Левкович, О. Зуськова // Вопросы психологии. - 1987. - № 4. - С. 128-134.

8. Алешина Ю. Е. Индивидуальное и семейное психологическое консультирование / Ю. Е. Алешина. - М. : Класс, 1999. - 243 с.

9. Семья. Социально-психологические и этические проблемы : справочник / В. И. Зацепин, Л. М. Бучинская, И. Н. Гавриленко [и др.] - К. : Политиздат Украины, 1990.

10. Варга А. Я. Системная семейная психотерапия. Краткий лекционный курс / А. Я. Варгай. - СПб. : Речь, 2001. - 289 с.

Отримано 20.10.17 